\title{
Identification of Training Needs of the Coconut Growers in Sri Lanka
}

\author{
Chaminda S. Herath
}

\begin{abstract}
The coconut farming sector in Sri Lanka has been facing many problems which eventually led to a decrease in production and profitability in coconut farming. The main reason for the decrease in production has been the non adoption of scientific technologies primarily due to the lack of technical knowledge of coconut growers on scientific cultivation practices. Hence, a study was undertaken to assess the technical knowledge and the level of adoption of management practices with a view to identify and prioritize the training needs of coconut growers'. Training needs of the growers were assessed using the Borich Needs Assessment Model. The identified training needs were filtered by quadrant analysis. The discrepancy score of grower's and the coconut development officers' of the three districts were used as the dimensions of the quadrant analysis. The training needs were identified under four categories namely, planting practices, fertilizer application practices, agronomy practices and pest management practices. The study revealed that the most knowledgeable aspect was the planting practices and the least knowledgeable was the pest management practices, as evidenced by higher level of adoption of planting practices and the least adoption of pest management practices. It was concluded from the study that the most desirable training need was on the pest management practices followed by fertilizer application practices in the coconut triangle of Sri Lanka.
\end{abstract}

Keywords: Adoption, Coconut, Discrepancy score, Knowledge, Perception, Training needs

\section{Background}

Sri Lanka is the fourth largest coconut producing country in the world accounting for total annual production of 2808 million nuts. The crop occupies 394,836 ha which represents $19 \%$ of the total cultivated land area. The coconut industry plays an important role in the economy of the country with a contribution of $2 \%$ to the gross domestic product (GDP). Being a major source of food, it provides $22 \%$ calorie intake in Sri Lankan diet. The domestic consumption in 2009 is 2269 million nuts (Statistics on coconut and oil palm, CRI, 2011).

The coconut yield depends on three major factors namely, the genetic makeup, the environment and the agricultural technologies / practices (Magat, 1978). The nut yield can be increased by $40 \%$ by the adoption of Coconut Research Institute's (CRI) recommended technologies (Liyanage, 1999).

Principal Technology Transfer Officer, Coconut Research Institute, Bandirippuwa Estate, Lunuwila, Sri Lanka. Email: hmcsherath@yahoo.com 
During the last two decades, coconut growers have been facing many problems, which ultimately resulted in a decline in production and profitability from their estates. The problems that the growers' confronted with are often complex, requiring detailed and valid information about many factors. This complexity is further compounded by the fact that growers usually have little or incomplete knowledge on the potential technologies to manage the problems (Hashemi et al., 2009).

Decisions on adopting recommended technologies are quite subjective and frequently depend on several factors which include personal belief and perceptions (Ajayi, 2000; Atreya, 2007). The scientific technologies are not adopted or have failed with negative social consequences mostly because the research has been conducted without adequate participation of farmers, with little consideration of farmers own knowledge, practices, and needs (Trutmann et al., 1996; Meerman et al., 1997; Prudent et al., 2007). If farmers are to manage their estates in the best way, they need to have technical knowledge as well as the "know-how" to carry out certain practices.

Witkin (1984) stated that "there is no model or conceptual framework for need assessment that is universally accepted and there is little empirical evidence of the superiority of one approach over another". Further, educational needs of a group could be identified better by using a variety of needs assessment models. Borich (1980) described an approach to conduct training needs based upon a discrepancy model. According to Borich a need can be considered as a discrepancy between "what is" and "what should be". This model proposed by Borich, is one of the most widely used models in agricultural education and agricultural extension agents, farmers and so on.

It is obvious that there is a difference between the information that farmers already have got and that which they should have to make appropriate and worthy decisions. Even when information gets through to the farmers, they may not be able to utilize the information properly because they lack the necessary background knowledge. In this case, more effort devoted to farmers' training is needed. Training programmes play a vital role in technology adoption decisions, providing farmers with the technical knowledge necessary for the selection of appropriate crop management practices (Prudent et al., 2007). Previous research has often emphasized the need to enhance farmers' awareness on various crop management practices particularly integrated pest management practices (Hashemi et al., 2008). The aims of this study were to explore coconut growers' knowledge and adoption level on coconut management practices and also to identify and prioritize their training needs.

\section{Materials and Methods}

\section{Study area and sampling method}

This study was conducted in the coconut triangle of Sri Lanka (covering Kurunegala, Gampaha and Puttlam districts) which covers the main coconut growing area. Stratified simple random sampling method was applied to collect data. Three strata have been identified to represent growers from Kurunegala, Gampaha and Puttlam districts. It was decided to select five Coconut Development Officers (CDO) ranges from each district and collect data from 10 growers from each CDO range. Therefore, the total sample size was 150 growers covering coconut triangle (50 from each district). Data were collected from Polgahawela, Weerambugedara, Dambadeniya, Narammala and Pothuhera CDO ranges to cover Kurunegala district and another randomly selected five CDO ranges namely; Urapola, Nittambuwa, Minuwangoda, Walpita and Gampaha to cover Gampaha District. For Puttlam district; Chilaw, Mahawewa, Arachchikattuwa, Madampe and Anamaduwa CDO ranges were selected.

\section{Data collection}

The data collection of both growers and Coconut Development Officers (CDOs) were carried out from August 2013 to November 2014. Data collection was done by employing a structured questionnaire through face to face interviews with growers and by mail survey from Coconut Development Officers (CDOs) who 
were attached to Kurunegala, Gampaha and Marawila regional officers of Coconut Cultivation Board. The same questionnaire was sent to CDOs and asked them to fill according to what they feel on importance, knowledge and adoption level of the each recommendation with respect to growers. The questions were derived from the technologies recommended by the Coconut Research Institute of Sri Lanka (CRI). All questions were based on 5 point Likert scale from 1 to 5 . The questions were categorized in to four main aspects namely; planting, fertilizer application, agronomy and pest management.

\section{Training need assessment}

The model proposed by Borich was employed in the present study (Borich, 1980). As per the model, weighted discrepancy score (WDS) was calculated for evaluating and ranking farmers' training needs.

$\mathrm{KDS}=\mathrm{KM}-\mathrm{IM}$

$\mathrm{ADS}=\mathrm{AM}-\mathrm{IM}$

$\mathrm{KWDS}=\mathrm{KDS} * \mathrm{IM}$

$\mathrm{AWDS}=\mathrm{ADS} * \mathrm{IM}$

$\operatorname{MWDS}=\frac{\text { KWDS }+ \text { AWDS }}{2}$

KDS $=$ Knowledge discrepancy score, $\mathrm{KM}=$ Knowledge mean, IM = Importance mean, ADS $=$ Adoption discrepancy score, $\mathrm{AM}=$ Adoption mean, KWDS = Knowledge weighted discrepancy score, AWDS $=$ Adoption weighted discrepancy score, MWDS $=$ Mean weighted discrepancy score

\section{Quadrant analysis}

Quadrant analysis was done by a mail survey with the Coconut Development Officers (CDOs) of Gampaha, Kurunegala and Puttlam. Questionnaires were sent to fifty CDOs, among them only 33 CDOs responded. Therefore the response rate was $66 \%$.

In order to filter the training needs, quadrant analysis was carried out. The quadrant analysis was done using a $2 \times 2$ matrix. It is based on two dimensions. One dimension is the growers' discrepancy score. The second dimension is the Coconut Development Officers' (CDO) discrepancy score.
The four quadrants in the quadrant analysis are (I) high discrepancy established by the growers and high discrepancy established by the CDOs. (II) high discrepancy established by the growers and low discrepancy established by the CDOs. (III) low discrepancy established by the growers and high discrepancy established by the CDOs. (IV) low discrepancy established by the growers and low discrepancy established by the CDOs. Witkin (1984) stated that those practices falling within quadrant (I) constitute priorities for training programmes. But those falling in quadrant (II) and (III) should be discussed and reinforced. Practices in quadrant (IV) could be interpreted as with no training needed.

\section{Results and discussion}

\section{Demographic characteristics of the respondents}

The comparison between demographic characters of coconut growers in Gampaha, Kurunegala and Puttlam districts is shown in Table 1. The average age of growers in Gampaha, Kurunegala and Puttlam districts were 48.7, 49.7 and 50.9 years, respectively. The majority of growers were male farmers. The coconut growers in Gampaha district have higher educational background than Kurunegala and Puttlam districts. In terms of time spent on farming, the majority of farmers in Gampaha and Putlam districts spent only part time in farming and the majority of growers in Kurunegala were full time farmers. The average farm size of Puttlam $(7.23 \mathrm{ac})$ was greater than Kurunegala (7.22 ac) and Gampaha (2.24 ac) districts.

\section{Reliability analysis}

Some concepts or constructs were not perfectly measured by a single item. Therefore, reliability analysis was conducted to ensure that the measured concept or construct was adequate and reliable. A commonly used measure of reliability is internal consistency. The most widely used internal consistency measure is Cronbach's alpha. The generally agreed lower limit for Cronbach's alpha is 0.7 , although it may decrease to 0.6 in exploratory research (Hair et al., 1998). As exploratory research, 
Table 1. Demographic characteristics of the respondents

\begin{tabular}{|l|r|r|r|}
\hline \multicolumn{1}{|c|}{ Parameter } & \multicolumn{1}{c|}{ Gampaha } & \multicolumn{1}{c|}{ Kurunegala } & \multicolumn{1}{c|}{ Puttlam } \\
\hline Mean Age (Years) & 48.7 & 49.7 & 50.9 \\
\hline Education (No. of years) (Mean) & 12.56 & 11.52 & 10.94 \\
\hline Gender (M/F ratio) (Male) & $80.00 \%$ & $78.00 \%$ & $54.69 \%$ \\
\hline Involvement in farming & & & \\
\hline Full time & $24.44 \%$ & $58.60 \%$ & $29.68 \%$ \\
\hline Part time & $75.56 \%$ & $41.40 \%$ & $70.32 \%$ \\
\hline Farm size (ac) (Mean) & 2.24 & 7.22 & 7.23 \\
\hline
\end{tabular}

Table 2. Cronbach's alphas of the variables in the model

\begin{tabular}{|l|l|c|}
\hline No. & \multicolumn{1}{|c|}{ Variable } & Cronbach's alpha \\
\hline 1 & Importance & 0.655 \\
\hline 2 & Knowledge & 0.866 \\
\hline 3 & Adoption & 0.841 \\
\hline
\end{tabular}

Table 3. Grower perception of importance, knowledge and adoption levels for the examined areas

\begin{tabular}{|c|c|c|c|c|c|c|}
\hline & \multirow[t]{2}{*}{$\begin{array}{c}\text { Importance } \\
\text { level }\end{array}$} & \multirow[t]{2}{*}{$\begin{array}{l}\text { Knowledge } \\
\text { level }\end{array}$} & \multirow[t]{2}{*}{$\begin{array}{l}\text { Adoption } \\
\text { level }\end{array}$} & \multirow{2}{*}{$\begin{array}{c}\text { Mean } \\
\text { Weighted } \\
\text { Discrepancy } \\
\text { Score }\end{array}$} & \multicolumn{2}{|c|}{$\begin{array}{c}\text { Rank } \\
\text { (Training needs) }\end{array}$} \\
\hline & & & & & $\begin{array}{l}\text { District } \\
\text { wise }\end{array}$ & $\begin{array}{l}\text { Recommendation } \\
\text { wise }\end{array}$ \\
\hline \multicolumn{7}{|c|}{ Planting practices } \\
\hline Gampaha & 4.54 & 4.16 & 3.93 & 2.16 & 4 & \multirow{3}{*}{$\begin{array}{c}4 \\
(3.12)\end{array}$} \\
\hline Kurunegala & 4.20 & 3.72 & 3.25 & 3.00 & 4 & \\
\hline Puttlam & 4.15 & 3.34 & 2.96 & 4.20 & 4 & \\
\hline \multicolumn{7}{|c|}{ Fertilizer application practices } \\
\hline Gampaha & 4.22 & 3.71 & 3.38 & 2.84 & 2 & \multirow{3}{*}{$\begin{array}{c}2 \\
(3.75)\end{array}$} \\
\hline Kurunegala & 4.35 & 3.70 & 3.14 & 4.02 & 2 & \\
\hline Puttlam & 4.30 & 3.47 & 3.11 & 4.38 & 3 & \\
\hline \multicolumn{7}{|c|}{ Agronomy practices } \\
\hline Gampaha & 4.29 & 3.84 & 3.46 & 2.75 & 3 & \multirow{3}{*}{$\begin{array}{c}3 \\
(3.70)\end{array}$} \\
\hline Kurunegala & 4.28 & 3.60 & 3.14 & 3.86 & 3 & \\
\hline Puttlam & 3.97 & 3.07 & 2.61 & 4.49 & 2 & \\
\hline \multicolumn{7}{|c|}{ Pest management practices } \\
\hline Gampaha & 4.14 & 3.36 & 2.84 & 4.30 & 1 & \multirow{3}{*}{$\begin{array}{c}1 \\
(6.00)\end{array}$} \\
\hline Kurunegala & 4.27 & 3.17 & 2.06 & 6.58 & 1 & \\
\hline Puttlam & 3.88 & 2.82 & 2.18 & 7.12 & 1 & \\
\hline
\end{tabular}


Cronbach's alpha with 0.6 lower limit was used as a criterion in this analysis. Table 2 presents the Cronbach's alpha of the variables in the model calculated by reliability analysis in SPSS. The Cronbach's alpha of the variables range from 0.866 (very reliable) to 0.655 (acceptable). Most of the variables in the model have shown a high internal consistency.

\section{Training needs of the coconut growers}

Growers in Gampaha district rated the recommendations in planting and agronomy practices as highly important, while growers in Kurunegala district rated fertilizer application and pest management practices as highly important to them. The lower scores for importance were recorded by growers in Puttlam district (Table 3).

For the growers in Gampaha district, the average knowledge levels for the four examined areas (planting, fertilizer application, agronomy and pest management) were 4.16, 3.71, 3.84 and 3.36 , respectively, indicating the fact that the growers in Gampaha district were most knowledgeable in the areas of planting, agronomy, fertilizer application and least knowledgeable in pest management. Further, their average adoption levels of the four examined areas were $3.93,3.38,3.46$ and 2.84 , respectively. It indicates that the lowest adopted practices were in pest management followed by fertilizer application. The mean knowledge levels of growers in Kurunegala district for four examined areas were 3.72, 3.70, 3.60 and 3.17, respectively, indicating the fact that the growers in Kurunegala area were the most knowledgeable with respect to planting and fertilizer application. In addition, their average adoption levels of the four examined areas were $3.25,3.14,3.14$ and 2.06 , respectively. Therefore, the adoption level was very low for pest management. The respective values for the growers in Puttalm district were 3.34, 3.47, 3.07 and 2.82 indicating that the growers in Puttlam district were the most knowledgeable with fertilizer application. Nevertheless, the adoption levels were 2.96, 3.11, 2.61 and 2.18, respectively. Therefore, the adoption level was very low for pest management (Table 3 ).
As far as training needs are concerned, the mean weighted discrepancy score (MWDS) for the growers in Gampaha district were 2.16, 2.84, 2.75 and 4.30, respectively, which indicates that there is a greater necessity for the training especially on pest management. For the growers in Kurunegala district the MWDS were 3.00, $4.02,3.86$ and 6.58 indicating that trainings on pest management is highly essential for sustainable coconut farming. Similarly, for the growers in Puttalm district, MWDS values were $4.20,4.38,4.49$ and 7.12 showing a high need of trainings in pest management (Table 3). Further, it indicates that the pest management was the first training need in the coconut triangle followed by fertilizer application.

\section{Training needs of growers with respect to recommendations}

Four major aspects were considered in the planting practices. They were; the recommended planting pit dimensions, planting method, space between palms and finally knowledge on planting materials. Growers in Gampaha, had better knowledge on the recommended planting pit dimensions and planting method compared to the growers of other two districts. The growers of Kurunegala district had better knowledge on recommended space between palms and planting materials. The knowledge level was low for growers of Puttlam district in all four recommendations (Table 4).

Among the three districts, MWDS was comparatively low for growers of Gampaha for two recommendations of the planting practices namely recommended planting pit dimensions and recommended planting method. Further, MWDS was high for growers in Puttlam, for recommended space between palms and planting materials (Table 4). It was noted that among the MWDS of three districts, Puttlam has reported the highest values. It implies that attending training programmes on planting practices is highly essential for them. However, knowledge on recommended planting materials and recommended space between palms were the topmost training need among the planting practices for the coconut triangle. 
Table 4. Perception of importance, knowledge and adoption levels of planting practices

\begin{tabular}{|c|c|c|c|c|c|c|}
\hline & \multirow[t]{2}{*}{$\begin{array}{l}\text { Importance } \\
\text { level }\end{array}$} & \multirow[t]{2}{*}{$\begin{array}{l}\text { Knowledge } \\
\text { level }\end{array}$} & \multirow[t]{2}{*}{$\begin{array}{l}\text { Adoption } \\
\text { level }\end{array}$} & \multirow{2}{*}{$\begin{array}{c}\text { Mean } \\
\text { Weighted } \\
\text { Discrepancy } \\
\text { Score }\end{array}$} & \multicolumn{2}{|c|}{$\begin{array}{c}\text { Rank } \\
\text { (Training needs) }\end{array}$} \\
\hline & & & & & $\begin{array}{l}\text { District } \\
\text { wise }\end{array}$ & $\begin{array}{l}\text { Recommendation } \\
\text { wise }\end{array}$ \\
\hline \multicolumn{7}{|c|}{ Recommended planting pit } \\
\hline Gampaha & 4.88 & 4.73 & 4.65 & 0.91 & 3 & \multirow{3}{*}{$\begin{array}{c}3 \\
(2.35)\end{array}$} \\
\hline Kurunegala & 3.96 & 3.43 & 3.01 & 2.93 & 2 & \\
\hline Puttlam & 3.90 & 3.28 & 2.86 & 3.22 & 3 & \\
\hline \multicolumn{7}{|c|}{ Recommended planting method } \\
\hline Gampaha & 4.70 & 4.58 & 4.45 & 0.88 & 4 & \multirow{3}{*}{$\begin{array}{c}4 \\
(2.15)\end{array}$} \\
\hline Kurunegala & 4.22 & 3.77 & 3.34 & 2.80 & 3 & \\
\hline Puttlam & 4.00 & 3.52 & 3.09 & 2.79 & 4 & \\
\hline \multicolumn{7}{|c|}{ Recommended space between palms } \\
\hline Gampaha & 4.43 & 4.00 & 3.65 & 2.65 & 2 & \multirow{3}{*}{$\begin{array}{c}2 \\
(3.68)\end{array}$} \\
\hline Kurunegala & 4.36 & 4.05 & 3.62 & 2.29 & 4 & \\
\hline Puttlam & 4.72 & 3.55 & 3.31 & 6.11 & 1 & \\
\hline \multicolumn{7}{|c|}{ Knowledge on recommended planting material } \\
\hline Gampaha & 4.15 & 3.33 & 2.95 & 4.20 & 1 & \multirow{3}{*}{$\begin{array}{c}1 \\
(4.27)\end{array}$} \\
\hline Kurunegala & 4.25 & 3.62 & 3.03 & 3.96 & 1 & \\
\hline Puttlam & 3.98 & 3.03 & 2.59 & 4.67 & 2 & \\
\hline
\end{tabular}

Table 5. Perception of importance, knowledge and adoption levels of fertilizer application practices

\begin{tabular}{|c|c|c|c|c|c|c|}
\hline & \multirow[t]{2}{*}{$\begin{array}{c}\text { Importance } \\
\text { level }\end{array}$} & \multirow[t]{2}{*}{$\begin{array}{l}\text { Knowledge } \\
\text { level }\end{array}$} & \multirow[t]{2}{*}{$\begin{array}{l}\text { Adoption } \\
\text { level }\end{array}$} & \multirow{2}{*}{$\begin{array}{c}\text { Mean } \\
\text { Weighted } \\
\text { Discrepancy } \\
\text { Score }\end{array}$} & \multicolumn{2}{|c|}{$\begin{array}{c}\text { Rank } \\
\text { (Training Needs) }\end{array}$} \\
\hline & & & & & $\begin{array}{l}\text { District } \\
\text { wise }\end{array}$ & $\begin{array}{l}\text { Recommendation } \\
\text { wise }\end{array}$ \\
\hline \multicolumn{7}{|c|}{ Application of YPM fertilizers } \\
\hline Gampaha & 4.35 & 4.00 & 3.83 & 1.90 & 5 & \multirow{3}{*}{$\begin{array}{c}4 \\
(3.27)\end{array}$} \\
\hline Kurunegala & 4.39 & 3.58 & 3.03 & 4.77 & 1 & \\
\hline Puttlam & 4.12 & 3.59 & 3.14 & 3.13 & 5 & \\
\hline \multicolumn{7}{|c|}{ Application of NPK fertilizers directly to the adult palm } \\
\hline Gampaha & 3.95 & 3.53 & 3.20 & 2.32 & 4 & \multirow{3}{*}{$\begin{array}{c}3 \\
(3.71)\end{array}$} \\
\hline Kurunegala & 4.43 & 3.96 & 3.36 & 3.39 & 5 & \\
\hline Puttlam & 4.78 & 3.76 & 3.52 & 5.43 & 2 & \\
\hline \multicolumn{7}{|c|}{ Application of APM fertilizes } \\
\hline Gampaha & 4.38 & 3.85 & 3.53 & 3.00 & 2 & \multirow{3}{*}{$\begin{array}{c}2 \\
(4.16)\end{array}$} \\
\hline Kurunegala & 4.22 & 3.56 & 3.08 & 3.78 & 3 & \\
\hline Puttlam & 4.78 & 3.74 & 3.41 & 5.72 & 1 & \\
\hline \multicolumn{7}{|c|}{ Application of organic fertilizers } \\
\hline Gampaha & 4.10 & 3.65 & 2.23 & 2.71 & 3 & \multirow{3}{*}{$\begin{array}{c}5 \\
(3.26)\end{array}$} \\
\hline Kurunegala & 4.05 & 3.62 & 2.70 & 3.59 & 4 & \\
\hline Puttlam & 4.31 & 3.62 & 3.38 & 3.49 & 4 & \\
\hline \multicolumn{7}{|c|}{ Application of organic + inorganic fertilizers } \\
\hline Gampaha & 4.30 & 3.53 & 3.10 & 4.24 & 1 & \multirow{3}{*}{$\begin{array}{c}1 \\
(4.30)\end{array}$} \\
\hline Kurunegala & 4.63 & 3.77 & 3.53 & 4.55 & 2 & \\
\hline Puttlam & 3.53 & 2.64 & 2.10 & 4.11 & 3 & \\
\hline
\end{tabular}


The aspects covered in the fertilizer application practices were; application of Young Palm Mixer (YPM) fertilizer, application of NPK fertilizers directly to the adult palm, application of Adult Palm Mixer (APM) fertilizer, application of organic fertilizer and application of organic + inorganic fertilizers.

Growers in Gampaha, reported satisfactory knowledge level in most of the fertilizer application practices, whereas growers in Kurunegala and Puttlam reported comparatively low knowledge level. MWDS scores in training needs were comparatively high for both growers in Kurunegala and Puttlam for almost all recommendations. It was noticeable that growers in three districts have higher MWDS values in application of organic and inorganic fertilizers (Table 5). However, application of organic and inorganic fertilizers and application of APM fertilizers were the top training needs in fertilizer application practices for coconut triangle.

Application of soil conservation methods, moisture conservation methods, intercropping and animal husbandry in coconut lands are the recommendations in the agronomy practices. Table 6 shows that, growers in the Puttlam district have the lowest knowledge level in all recommendations except animal husbandry. In addition, MWDS scores of priority in training needs were high for growers in Puttlam for intercropping and moisture conservation methods. As far as the coconut triangle is concerned, intercropping with coconut and application of moisture conservation methods were the top training needs.

The recommendations of the pest management practices were; management of mite, red weevil, black beetle, plesispa beetle, termite, mammals and management of diseases. As far as the knowledge level was concerned, the lowest knowledge level of pest management practices was in the growers of Puttalam district (Table. 7).

MWDS scores of priority in training needs were high for the growers in three districts namely Gampaha, Kurunegala and Puttlam (Table. 7). It was noticeable that MWDS for management of mammals was very high. The priority training needs of the Gampaha district were the management of red weevil, mammals followed by management of plesispa beetle. The top three training needs of the Kurunegala district were the; management of red weevil, black beetle and mammals. Finally the respective training needs of the growers in Puttalm district were management of mammals, black beetle and red weevil. Irrespective of the districts, the top three training needs of the coconut triangle were; management of red weevil, mammals and black beetle.

According to the Borich need assessment model, the most desirable training needs were shown in Table 8 . The topmost priority training need was for the management of red weevil. The first six priority training needs were for pest management category and the next priority was for fertilizer application practices.

\section{Quadrant analysis}

The quadrant analysis was carried out to filter the training needs. Therefore, another dimension was added to the model. It was CDOs perception on growers' knowledge and adoption levels. The first dimension of the quadrant analysis was; growers weighted discrepancy score and the second dimension was CDOs view on growers' knowledge and adoption levels as a weighted discrepancy score. The result shows in the Table 9 and Figure 1.

According to the quadrant analysis, 10 of the 20 recommendations were classified in quadrant $I$ as a result of receiving high mean weighted discrepancy scores from both growers and CDOs. Quadrant II contained no recommendation that received high MWDS from growers and low MWDS from CDOs. Four recommendations were located in quadrant III, indicating low MWDS from growers and high MWDS from CDOs. As a result of receiving low MWDS from both growers and CDOs, six recommendations were located in quadrant IV. The recommendations that were located in the quadrant I belongs to the highly desirable training need category (Figure 1, Table 9). As a result of combining an additional dimension to the model by quadrant analysis, it can be assumed that the quadrant analysis yields more 
Table 6. Perception of importance, knowledge and adoption levels of Agronomy practices

\begin{tabular}{|c|c|c|c|c|c|c|}
\hline & \multirow[t]{2}{*}{$\begin{array}{c}\text { Importance } \\
\text { level }\end{array}$} & \multirow[t]{2}{*}{$\begin{array}{c}\text { Knowledge } \\
\text { level }\end{array}$} & \multirow[t]{2}{*}{$\begin{array}{c}\text { Adoption } \\
\text { level }\end{array}$} & \multirow{2}{*}{$\begin{array}{c}\text { Mean } \\
\text { Weighted } \\
\text { Discrepancy } \\
\text { Score }\end{array}$} & \multicolumn{2}{|c|}{$\begin{array}{c}\text { Rank } \\
\text { (Training Needs) }\end{array}$} \\
\hline & & & & & $\begin{array}{l}\text { District } \\
\text { wise }\end{array}$ & $\begin{array}{l}\text { Recommendation } \\
\text { wise }\end{array}$ \\
\hline \multicolumn{7}{|c|}{ Soil conservation methods (Contour drains, Contour bunds SALT, Terraces) } \\
\hline Gampaha & 4.35 & 3.78 & 3.45 & 3.20 & 1 & \multirow{3}{*}{$\begin{array}{c}3 \\
(3.65)\end{array}$} \\
\hline Kurunegala & 4.46 & 3.79 & 3.29 & 4.11 & 1 & \\
\hline Puttlam & 3.03 & 2.09 & 1.57 & 3.66 & 3 & \\
\hline \multicolumn{7}{|c|}{ Moisture conservation methods (Mulching, Husk burial) } \\
\hline Gampaha & 4.20 & 3.75 & 3.40 & 2.62 & 3 & \multirow{3}{*}{$\begin{array}{c}2 \\
(3.73)\end{array}$} \\
\hline Kurunegala & 4.44 & 3.84 & 3.41 & 3.64 & 4 & \\
\hline Puttlam & 4.55 & 3.72 & 3.21 & 4.94 & 2 & \\
\hline \multicolumn{7}{|c|}{ Intercropping } \\
\hline Gampaha & 4.55 & 4.13 & 3.83 & 2.61 & 3 & \multirow{3}{*}{$\begin{array}{c}1 \\
(4.13)\end{array}$} \\
\hline Kurunegala & 4.25 & 3.56 & 3.10 & 3.92 & 2 & \\
\hline Puttlam & 4.22 & 3.14 & 2.53 & 5.86 & 1 & \\
\hline \multicolumn{7}{|c|}{ Animal husbandry in coconut lands } \\
\hline Gampaha & 4.08 & 3.73 & 3.18 & 2.54 & 4 & \multirow{3}{*}{$\begin{array}{c}4 \\
(3.27)\end{array}$} \\
\hline Kurunegala & 3.93 & 3.20 & 2.74 & 3.76 & 3 & \\
\hline Puttlam & 4.09 & 3.33 & 3.12 & 3.52 & 4 & \\
\hline
\end{tabular}

Table 7. Perception of importance, knowledge and adoption levels of Pest management practices

\begin{tabular}{|c|c|c|c|c|c|c|}
\hline & \multirow[t]{2}{*}{$\begin{array}{c}\text { Importance } \\
\text { level }\end{array}$} & \multirow[t]{2}{*}{$\begin{array}{c}\text { Knowledge } \\
\text { level }\end{array}$} & \multirow[t]{2}{*}{$\begin{array}{c}\text { Adoption } \\
\text { level }\end{array}$} & \multirow{2}{*}{$\begin{array}{l}\text { Mean Weighted } \\
\text { Discrepancy } \\
\text { Score }\end{array}$} & \multicolumn{2}{|c|}{$\begin{array}{c}\text { Rank } \\
\text { (Training Needs) } \\
\end{array}$} \\
\hline & & & & & $\begin{array}{l}\text { District } \\
\text { wise }\end{array}$ & $\begin{array}{l}\text { Recommendation } \\
\text { wise }\end{array}$ \\
\hline \multicolumn{7}{|c|}{ Management of Mite } \\
\hline Gampaha & 4.35 & 3.90 & 2.85 & 4.24 & 4 & \multirow{3}{*}{$\begin{array}{c}6 \\
(5.18)\end{array}$} \\
\hline Kurunegala & 4.53 & 4.03 & 2.87 & 4.88 & 6 & \\
\hline Puttlam & 4.66 & 3.47 & 3.09 & 6.42 & 5 & \\
\hline \multicolumn{7}{|c|}{ Management of Red Weevil } \\
\hline Gampaha & 4.58 & 3.65 & 2.98 & 5.77 & 1 & \multirow{3}{*}{$\begin{array}{c}1 \\
(7.93)\end{array}$} \\
\hline Kurunegala & 4.70 & 2.70 & 2.10 & 10.71 & 1 & \\
\hline Puttlam & 4.38 & 3.16 & 2.26 & 7.32 & 3 & \\
\hline \multicolumn{7}{|c|}{ Management of Black Beetle } \\
\hline Gampaha & 4.30 & 3.65 & 3.15 & 3.87 & 6 & \multirow{3}{*}{$\begin{array}{c}3 \\
(6.52)\end{array}$} \\
\hline Kurunegala & 4.43 & 3.29 & 2.15 & 7.56 & 2 & \\
\hline Puttlam & 4.50 & 3.10 & 2.28 & 8.15 & 2 & \\
\hline \multicolumn{7}{|c|}{ Management of Plesispa Beetle } \\
\hline Gampaha & 4.15 & 3.33 & 2.73 & 4.66 & 3 & \multirow{3}{*}{$\begin{array}{c}5 \\
(5.40)\end{array}$} \\
\hline Kurunegala & 3.89 & 2.84 & 2.08 & 5.57 & 5 & \\
\hline Puttlam & 4.12 & 2.83 & 2.52 & 5.97 & 6 & \\
\hline \multicolumn{7}{|c|}{ Management of Termite } \\
\hline Gampaha & 3.93 & 3.43 & 3.10 & 2.60 & 7 & \multirow{3}{*}{$\begin{array}{c}7 \\
(3.70)\end{array}$} \\
\hline Kurunegala & 4.13 & 3.53 & 3.01 & 3.56 & 7 & \\
\hline Puttlam & 4.02 & 3.07 & 2.50 & 4.95 & 7 & \\
\hline \multicolumn{7}{|c|}{ Management of Mammals } \\
\hline Gampaha & 4.05 & 3.00 & 2.63 & 5.01 & 2 & \multirow{3}{*}{$\begin{array}{c}2 \\
(7.40)\end{array}$} \\
\hline Kurunegala & 4.18 & 2.75 & 2.15 & 7.25 & 3 & \\
\hline Puttlam & 4.31 & 2.36 & 1.64 & 9.96 & 1 & \\
\hline \multicolumn{7}{|c|}{ Management of Diseases } \\
\hline Gampaha & 3.60 & 2.60 & 2.43 & 3.91 & 5 & \multirow{3}{*}{$\begin{array}{c}4 \\
(5.82)\end{array}$} \\
\hline Kurunegala & 3.96 & 2.94 & 1.70 & 6.49 & 4 & \\
\hline Puttlam & 3.43 & 1.72 & 1.02 & 7.07 & 4 & \\
\hline
\end{tabular}


Table. 8 Priority of training needs (Growers perspective)

\begin{tabular}{|l|l|c|c|}
\hline Category & Recommendation & MWDS & Rank \\
\hline Pest management & Management of red weevil & 7.93 & 1 \\
\hline Pest management & Management of mammals & 7.40 & 2 \\
\hline Pest management & Management of black beetle & 6.52 & 3 \\
\hline Pest management & Management of diseases & 5.82 & 4 \\
\hline Pest management & Management of plesispa beetle & 5.40 & 5 \\
\hline Pest management & Management of mite & 5.18 & 6 \\
\hline Fertilizer application & Application of organic + inorganic fertilizer & 4.30 & 7 \\
\hline Planting practices & Recommended planting materials & 4.27 & 8 \\
\hline Fertilizer application & Application of APM & 4.16 & 9 \\
\hline Agronomy practices & Intercropping with coconut & 4.13 & 10 \\
\hline
\end{tabular}

Table 9. Training needs of coconut growers as determined by quadrant analysis

\begin{tabular}{|c|l|c|c|c|}
\hline \multirow{2}{*}{ Quadrant } & \multicolumn{1}{|c|}{ Recommendation } & \multicolumn{2}{c|}{ MWDS } & \\
\cline { 3 - 5 } & & Growers & CDOs & Rank \\
\hline I & Management of red weevil & 7.93 & 6.58 & $1(7.25)$ \\
\hline & Management of black beetle & 6.52 & 5.50 & $2(6.01)$ \\
\hline & Management of plesispa beetle & 5.40 & 5.85 & $3(5.62)$ \\
\hline & Management of mite & 5.18 & 3.73 & $8(4.45)$ \\
\hline & Management of diseases & 5.82 & 3.81 & $6(4.81)$ \\
\hline & Management of mammals & 7.40 & 3.64 & $4(5.52)$ \\
\hline & $\begin{array}{l}\text { Application of organic + inorganic } \\
\text { fertilizers }\end{array}$ & 4.3 & 5.59 & $5(4.94)$ \\
\hline & Application of APM fertilizers & 4.16 & 3.53 & $10(3.84)$ \\
\hline & $\begin{array}{l}\text { Intercropping with coconut } \\
\text { III }\end{array}$ & 4.13 & 4.24 & $9(4.19)$ \\
& $\begin{array}{l}\text { Knowledge on recommended } \\
\text { planting materials }\end{array}$ & 4.10 & 5.21 & $7(4.74)$ \\
& $\begin{array}{l}\text { Application of moisture } \\
\text { conservation methods }\end{array}$ & 3.73 & 5.02 & $1(4.37)$ \\
\hline & $\begin{array}{l}\text { Application of direct fertilizer on } \\
\text { adult palms }\end{array}$ & 3.71 & 4.66 & $2(4.18)$ \\
\hline & $\begin{array}{l}\text { Application of YPM fertilizer } \\
\text { mixer }\end{array}$ & 3.26 & 4.39 & $3(3.82)$ \\
\hline & Application of organic fertilizer & 3.26 & 4.34 & $4(3.80)$ \\
\hline & Management of Termite & 3.70 & 3.19 & $1(3.44)$ \\
\hline & $\begin{array}{l}\text { Recommended space between } \\
\text { palms }\end{array}$ & 3.68 & 2.90 & $2(3.29)$ \\
\hline & $\begin{array}{l}\text { Animal husbandry in coconut } \\
\text { lands }\end{array}$ & 3.39 & 2.92 & $3(3.15)$ \\
\hline & $\begin{array}{l}\text { Application of soil conservation } \\
\text { methods }\end{array}$ & 3.66 & 1.66 & $4(2.66)$ \\
\hline & Recommended planting hole & 2.35 & 1.85 & $5(2.10)$ \\
\hline & Recommended planting method & 2.15 & 1.97 & $6(2.06)$ \\
\hline & & & \\
\hline
\end{tabular}




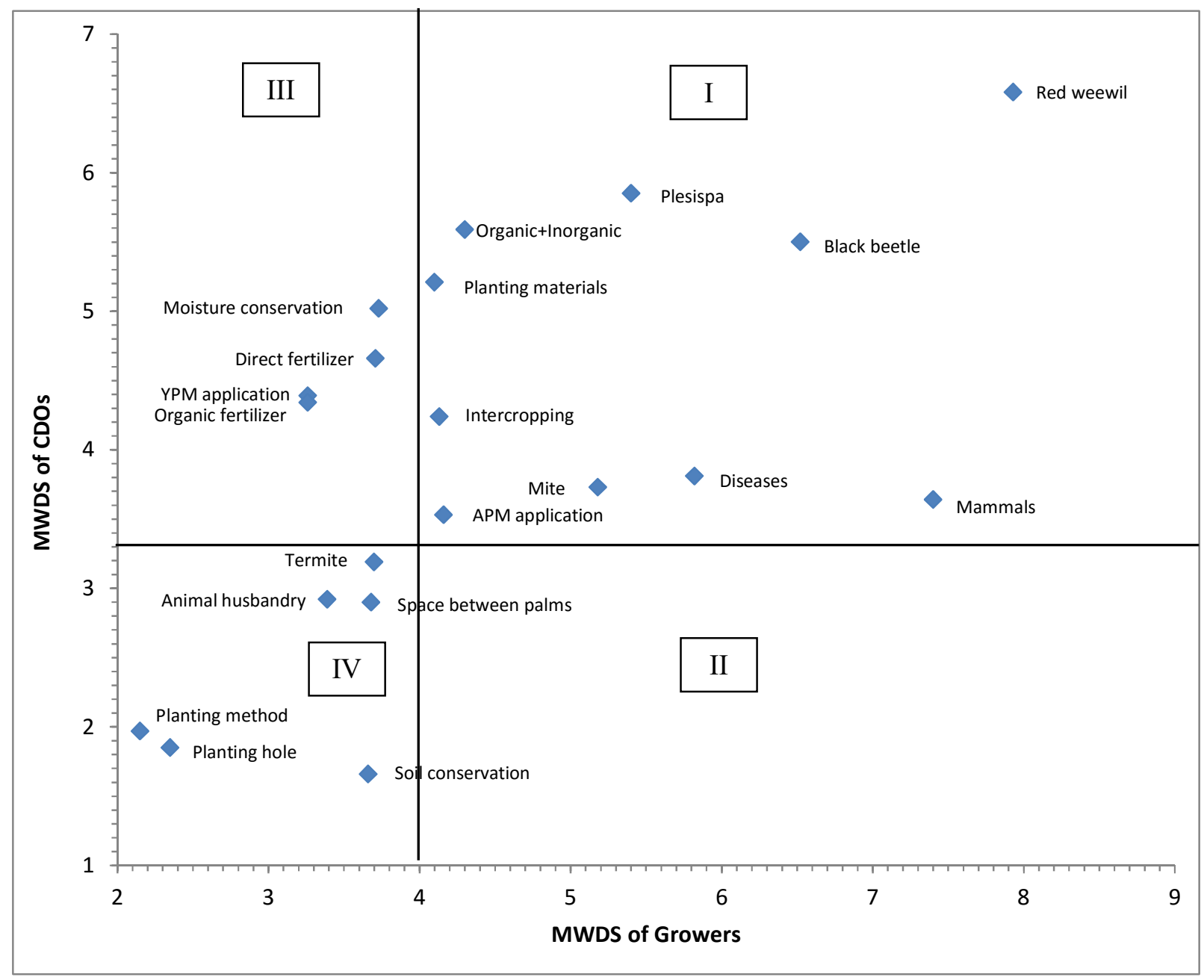

Figure 1. Quadrant analysis of training needs

Table 10. Correlation between training need of pest management and socioeconomics characters

\begin{tabular}{|l|c|}
\hline \multicolumn{1}{|c|}{ Characteristics } & Training need \\
\hline Age (Years) (Mean) & $0.200^{*}$ \\
\hline Education (No of years) (Mean) & $-0.098^{\text {ns }}$ \\
\hline Gender \% (M/F ratio) (male) & $0.174^{\text {ns }}$ \\
\hline Time spend on farming (part time, full time) & $-0.265^{* *}$ \\
\hline Farm size (ac.) (Mean) & $-0.257^{* *}$ \\
\hline
\end{tabular}

** Correlation is significant at the 0.01 level (2-tailed)

* Correlation is significant at the 0.05 level (2-tailed) 
accurate results. It is noticeable that both Borich model and quadrant analysis yields the same set of recommendations for highly desirable training needs but with a different priority order.

When the quadrant I is considered, there are six recommendations out of ten which belong to pest management practices. Two recommendations were belongs to fertilizer application practices. Therefore, the highly desirable training needs are the pest management practices and fertilizer application practices. These findings were supported by the diagnostic survey carried out by the Coconut Research Institute during 2006. It revealed that, only $21 \%$ and $27 \%$ of coconut growers were aware of control methods of red weevil and black beetle respectively. Further, 43\% of growers were not aware of the plesispa beetle. It was revealed that $31 \%$ of growers have never applied fertilizer in their fields and $14 \%$ of growers were only aware of adult palm fertilizer mixtures (APM) (Peiris et al., 2006).

Table 10 shows the correlation between the training needs of pest management and socioeconomics characters. Age of the respondents has a significant and positive relationship with training needs of pest management. Time spent on farming and average farm size have significant and negative relationships with training needs of pest management. But there was no significant relationship between gender and education with training needs of pest management.

\section{Conclusion}

The data presented in this paper provide the details of growers' knowledge level, adoption level of technologies and future training needs of different practices for coconut cultivation in the coconut triangle of Sri Lanka. Growers showed different levels of competence in coconut farming as a result of their different levels of training and their different background. Planting practices and pest management are the most knowledgeable and the least knowledgeable practices, respectively, for coconut growers included in this study. Further, the most common adopted practice was planting practices and the least adopted practice was pest management.

It is noticed that both Borich model and quadrant analysis yields the same set of recommendations for highly desirable training needs, but with different priority orders. Therefore, it can be assumed that when identifying the training needs either the Borich model or the quadrant analysis model are acceptable approaches that yield similar results. When designing training programmes, it should be focused on part time growers, small holder growers and not the younger generation.

Finally, it can be concluded that the most desirable training categories are pest management practices followed by fertilizer application practices in the coconut triangle of Sri Lanka.

\section{Acknowledgements}

The author would like to express his profound gratitude to the Director, Additional Director and Deputy Director (Research) of the Coconut Research Institute of Sri Lanka for giving permission to carry out this study.

\section{References}

Ajayi, O.C., 2000. Pesticide use practices, productivity and farmers' health: the case of cotton-rice systems in Cote d'lvoire, West Africa. In: Pesticide Policy Project, Special Issue Publication Series No. 3. University of Hanover, Germany.

Atreya, K., 2007. Pesticide use knowledge and practices: a gender differences in Nepal. Environ. Res. 104: 305-311

Borich, G.D., 1980. A needs assessment model for conducting follow-up studies. J. Teach. Educ. 31: 39-40.

Hair, J.F., Anderson, R.E.J., Tatham, R.L. and Black, W.C., 1998. Multivariate data analysis, (5 ${ }^{\text {th }}$ ed.), New Jersey: PrenticeHall.

Hashemi, S.M., Mokhtarnia, M., Erbaugh, J.M., Asadi, A., 2008. Potential of extension workshops to change farmers' knowledge 
and awareness of IPM. Sci. Total Environ. 407: 84-88.

Hashemi S.M., Hosseini S.M., Damalas C.A., 2009. Farmers' competence and training needs on pest management practices: participation in extension workshops. Crop Prot 28: 934-939.

Liyanage, M. de S., 1999. Scientific cultivation of coconut, Coconut Research Institute, Lunuwila, Sri Lanka: 2.

Magat, S. S., 1978. A review of fertilizer studies on coconut, Philippine Journal Coconut Studies., 3(2): 51-69.

Meerman, F., Bruinsma, W., Van Huis, A., Ter Weel, P., 1997. Integrated pest management: smallholders fight back. ILEIA Newsl. 13(4): 4

Peiris et al, 2006. Coconut research development and dissemination of technologies Growers perception. A diagnostic survey report, Coconut Research Institute, Lunuwila, Sri Lanka: 33-77.

Prudent, P., Loko, S., Deybe, D., Vaissayre, M., 2007. Factors limiting the adoption of IPM practices by cotton farmers in Benin: a participatory approach. Exp. Agr. 43: 113124.

Statistics on coconut and oil palm. 1, 2011. Coconut Research Institute, Lunuwila, Sri Lanka: 18.

Trutmann, P., Voss, J., Fairhead, J., 1996. Local knowledge and farmer perceptions of bean diseases in the Central African Highlands. Agr. Human Values 13: 64-70.

Witkin, B. R., 1984. Assessing needs in educational and social programs. San Francisco, CA: Jossey-Bass Inc. 